\title{
"I am what I am Not"- Reflections of the Re-Construction of My Identity as a Novice Postgraduate Supervisor At A University Of Technology In South Africa
}

\author{
Veena P. Rawjee \\ Department of Public Relations, Durban University of Technology, South Africa \\ Email: rawjeeve@dut.ac.za
}

\section{Doi:10.5901/mjss.2014.v5n20p1360}

\section{Abstract}

\begin{abstract}
The overall aim of this paper is to explore my experiences as a novice postgraduate supervisor through the process of reflection. This study adopts a qualitative approach and uses self-reflection as a method of enquiry by reflecting and documenting personal experiences and practices of postgraduate supervision. The findings are analysed so as to give meaning and to make sense of the supervision process. The results reflect that the journey of postgraduate supervision, in part, has not only resulted in the development of the student, but has also resulted in the academic journey of development of myself. This process has entailed the re-establishment of my academic identity of working within a redefined context of a University of Technology (UoT). Whereas, in the past my key role at a Technikon was undergraduate study only, I have had to reconstruct and re-negotiate my identity to integrate the scholarship of research, which has to an extent, contributed positively to my professional development. Based on these findings I suggest that, to add credence to the supervisory process and to the novice supervisors experiences, a postgraduate supervision module is introduced as a core study module for all first-time supervisors before they embark on their journey of supervision. This process could possibly assist the novice researcher to renegotiate an identity for possible inclusion into the broader academic community and to build supervision capacity at the newly established UoT's in South Africa.
\end{abstract}

Keywords: Postgraduate Studies Supervision; University of Technology; Identity

\section{Introduction}

Higher education institutions play a pivotal role in the social, cultural and economic development within developing countries. In South Africa, Higher Education South Africa (HESA, 2008), maintains that the overall aim of higher education institutions is to meet the learning needs and aspirations of young individuals. After apartheid, in 1994, the new democratic government commenced with a new agenda of change and transformation to reshape the South African society. Higher education institutions were on the top of this agenda of change (May, 2004). The Ministry of Education (2001) outlined a vision of a single co-ordinated higher education system through mergers. Pityana (2004) maintains that as a result of the mergers higher education institutions now provide a sphere for public debate and encourage the development of a reflective capacity and a willingness to address and renew ideas and practices. Pityana (2004) further adds that higher education institutions are also engaged in the pursuit of academic scholarship and intellectual inquiry through research, learning and training with the main aim of assisting students to make the best use of their talents and skills. The reorganisation of the higher education landscape in South Africa has highlighted Boyer's (1990) three forms of scholarships: teaching, research and service. Whereas, previously, South African tertiary institutions were classified as either teaching-oriented institutions or research-oriented institutions, mergers and the reorganisation processes changed the focus of many higher education institutions in South Africa. The change re-positioned Technikons (previously teaching-oriented institutions) as Universities of Technology (UoT's). Research and postgraduate supervision became key drivers at UoT's and they were re-positioned, like traditional universities, within the research arena. Postgraduate study became available in most disciplines at UoT's.

Since, my role as an academic within a UOT has been re-defined to incorporate research as a core function. Chetty's (2010) maintains that that the adoption of a role of researcher required a major change in the identity of the UoT educator. In the past my key role as an academic was undergraduate study only, however after the formation however after the formation of UoT's I had to reconstruct and re-negotiate my academic identity to integrate the scholarship of research. Since, I have had to make considerable changes to accommodate this new identity. The overall aim of this paper is to therefore reflect on my experiences of how, by taking on the role of a postgraduate supervisor at a UoT, I have had to re-negotiate my identity to integrate the scholarship of research which has contributed positively to my professional 
development. My findings (my reflections) are categorised based on two themes, which are firstly the context within which I supervise and secondly what it means to me to be a supervisor at a UoT.

\section{Methodology}

This study adopts a qualitative approach and uses self-reflection as a method of enquiry. Self-reflective research involves an 'enquiry conducted by the self into the self' (McNiff, 2000). It examines one's own practice against one's own pedagogical values. Etlers (2006) refers to this process as the 'mirror test'. Bates and Pardo (2006) maintain that a selfevaluative investigation of one's own supervision practice could provide skills furthering my professional transformation and growth, and that of postgraduate students. Self-reflection captures how people make sense of the world. The event is presented by recording of events. It is also captured in the form of internalized soliloquies (Athens, 1994; Ezzy, 1998). These are the conversations one has with oneself where the individual is the primary sense-making agent in the construction of his/her own identity (Giddens, 1991; Schwandt, 1998).

The context of this study is a UoT in KwaZulu-Natal. My practice as a postgraduate supervisor is the unit of analysis. Data was gathered through personal reflections by drawing from student's responses and narratives during the supervision meetings and electronic communication (e-mails) from students. This data was used to 'support reflexivity' (Pinnegar \& Hamilton 2009). The data was carefully reflected on and analysed by retelling or "restorying" them into a framework which traces the journey of identity reconstruction through the process of supervision (Creswell, 2008).

\section{Findings and Analysis}

The findings (my reflections) are categorised based on two themes; firstly, within the context of identity formation and secondly, the meaning of being a supervisor at a UoT.

\subsection{Novice supervisors: identities in the making}

According to Amundsen and McAlpine (2009) supervision is central to the work of most academics and is inherently a social activity. Studies (Pare', McAlpine \& Starke-Meyerring, 2006) show that engaging in academic work, underpins one's identity as an academic. According to Stuart Hall (1996) 'identity' is the meeting point, between, the discourses and practices which, on one hand, hail us into place as the social subjects of particular discourses, and on the other hand, the processes which produces subjectivities, which construct us as subjects. Stryker (2007) further maintains that identity theory has its referent in a literature that seeks to develop and examine empirically a theoretical explanation of role choice behaviour. Hence the notion of "I am what I am not" underpins my identity as supervisor. My role of the supervisor is therefore very much dependent on my identity. This can possibly be attributed to firstly, to my experiences of being supervised as a postgraduate student; secondly my postgraduate supervisory capacity development and thirdly my practical experiences gained through the supervisory processes over a period of time. As a novice supervisor, taking on the role of postgraduate supervisor therefore meant the re-construction and re-negotiation of my identity as an academic. The re-negotiation of my identity possibly took place when I was socialised into the scholarship of research in order to be recognised within the broader academic community. Therefore, using Hall's (1996) definition as a theoretical base, I argue that postgraduate supervision has placed me as a social subject within my academic discourse. This has not only resulted in the development of my student's identity, but also permitted me, as a novice supervisor, to develop and thereby establish an academic identity myself for possible inclusion into the broader academic community. Based on this, I use Halls' identity definition to test this proposition. I do so by reflecting on my personal experiences and practices as a novice postgraduate supervisor. These reflections not only showcase the development of my postgraduate students, but also show how through the supervision process, I have developed and re- negotiated my identity to integrate into the scholarship of research and how I have become more consciously aware of my practice to further develop my ability to make sound professional judgements relating to postgraduate supervision, and this process has contributed positively to my professional development.

\subsection{What does being a supervisor mean to me as a UOT academic?}

White (2012) maintains that "The work of academics has intensified, but the focus for most remains on teaching, research and contribution to service. Institutional imperatives and the positioning of universities impact significantly on how academics fashion themselves to fit in with expectations and demands. There is, of course, no simple version of scholarly 
identity and Barnett (2000) has called attention to the 'super complexity' of academic work". This quote provides an appropriately describes the context within which I function as an academic. As a supervisor I play a facilitative role by creating an enabling space through which I attempt to provide constructive feedback to the student. I accept that as an educator I function in a trans-cultural and trans-historical space by virtue of our multicultural nation and our unjust political past. In addition, I also accept, and take cognisance that the space within which I functioned as an academic within a Technikon was very is fluid and porous. The political changes in South Africa prompted the re-organisation for the education landscape. Therefore, in 2003 when Technikons were merged and awarded university status, I saw postgraduate study as a stepping stone for both my personal and professional development. I therefore completed a $\mathrm{PhD}$, and my transition from being supervised to supervising was instantaneous as I had to embrace the scholarship of research.

I still see the context within which I operate in transition, which Chetty (2010) describes as a context where UoT's have no other choice but to increase their published research output if they want to survive as viable tertiary institutions, nationally and globally. In reflecting on these events I realise that my key performance areas have changed. I am now individually assessed based on my postgraduate student throughput and my research output. This means that I now operate in a context where the production of knowledge is a key factor in the judgement of my performance as an academic. This changed context has forced me to put structured systems into place to assist of me to cope with my additional responsibilities of postgraduate supervision. In devising these systems I have discovered that the process of supervision ought to be pragmatic and that my knowledge and ability to teach students about the logic and methodology of research is a core skill that I require.

At first, critiquing postgraduate students work; assisting with the formulation of a conceptual framework and devising a methodology for someone else's study other than mine was rather daunting. Despite the feelings of trepidation, I knew that I had to take on a new identity to stake a claim as an academic. I realised that to be more productive, I had to negotiate a supervisory style in order to establish my identity. Supervisory styles as described by Gatfield (2005) can be categorised into four domains, i.e. pastoral; contractual; laissez-faire style and directorial. In the laissez-faire style the supervisor is non-directive and not committed to high levels of personal interaction. The pastoral style sees the supervisor as providing considerable personal care and support but not necessarily in a task-driven directive capacity. In the directorial style the supervisor has a close and regular interactive relationship with the candidate, but avoids non-task issues. The contractual style requires that the supervisor is able to administer direction and exercises good management skills and interpersonal relationships.

My immediate response was to choose the contractual style of supervision. However, on reflecting on these styles I have found that the supervision process and the relationships are most likely to change over time as confirmed by Gurr (2001). This realisation occurred, in my case, occurred during the supervision of my doctoral student. Initially, a laissezfaire supervision style was adopted where minimum support was sought by the student as the student maintained that she was thinking and conceptualizing her topic. I initially assisted her by setting up a meeting with the postgraduate librarian to assist her with sourcing appropriate readings. She worked through this stage independently and maintained that she did not need much help form me. Although the student registered as a doctoral student in February 2012; submission of work only started around April 2013. During this period minimum meeting time was required. I only started meeting regularly with her March 2013, when she requested advice on conceptual issues.

As the student began working on the proposal and started conceptualising her problem statement, her interaction with me increased and I started setting up more formal meetings with her to help with conceptualising her study. Once her proposal was completed we negotiated a contract and negotiated timeframes for the completion of the dissertation. The student began preparing her literature review and met with me once a week so to assist with her with the structure of her literature review and at the same time the development of the research instrument. During this phase she required high levels of "support" and high levels of "structure" from me. Once this phase is completed, and she tied up her literature review and she required reduced amounts of my time. There were low levels of my involvement again during the data collection phase. However, as she moved into the write-up stage she needed reduced levels of 'support' and yet still needed high levels of support for "structure". Hence the supervisory style will possibly move back to the "directorial" position.

However, the styles adopted in the above case are not consistent for every student. In many instances, postgraduate studies require a certain level of commitment form the student and if the student is not committed and structured, the study is not completed within a reasonable time. Therefore, the context within which I supervise is very complex and is multi-layered/multifaceted and very fluid. My style of supervision would vary from student to student depending on the needs of that student. The socio-economic context of the student impacts on the students' performance and his choice to register for a postgraduate study. My experiences vary from student to student and I have developed 
over the years to accommodate the different kinds of postgraduate students.

Postgraduate supervision has greatly improved my critical thinking skills. Reading students' academic discourses from varied backgrounds has helped me to assent to the notion that each postgraduate student is unique. The journey that I have passed through since I began postgraduate supervision has led me to the conclusion that each supervision experience is distinctive. My postgraduate supervision experiences have therefore varied from student to student.

Postgraduate students re-enter the academic arena for different reasons and at different times in their lives. Each student is unique as each one bring with them a multiplicity of experiences based on their varied socio-political and economic contexts. The postgraduate supervision experience for me has therefore been both unique and diverse. This for me represents a sharp juxtaposition, to an extent, because the process of research, in a sense, is said to be pragmatic and logical, however my experiences with each student has been predominantly diverse and unique. I also feel that as a supervisor ought to be task orientated; structured; supportive; accommodating; empathetic and flexible.

By working within varied contexts has allowed me to read and accept that students have different writing styles and each individual possess different levels of academic writing skills This realisation has alerted me to the view that firstly a student has to be tutored to develop academic writing skills (writing workshops/library orientations/referencing workshops/sourcing current and relevant academic texts). Once the student understands the academic writing process, it is crucial to help to develop the student's skills to conceptualise the study. This happens after an in-depth discussion focussing on the current discussions; arguments, latest developments and debates relating to the chosen field of study. A broad focussing question is agreed upon by the student and the supervisor. Using current and relevant literature the student is taught relevant skills on how make connections and weave texts together. This helps the supervisor and the student to develop a deeper understanding of the study as it outlines the current and critical information about the area of specialisation. Using the overall aim of the study as a focal point, the student is helped to divide the study into sub sections. This process allows the student to envisage how the study will unfold and therefore assists in helping both the student and the supervisor to develop a vision for the study. Based on this, a plan outlining the timeframe for completion of the study is plotted in relation to the student's personal and professional life. This timeframe reflects a journey that the student will have to go through in order to fulfil the outcomes of both the study and the postgraduate qualification outcome. The timeframe is plotted to illustrate the research process and each step in given a timeframe and a specific date for completion. In this way the student is able to dissect the study in small achievable steps. Upon completion of the study the student is encouraged to compile a journal article with the help of the supervisor. This process allows comments from peers in the field of specialisation. The comments received from the peer reviewers of the journal allow the student to critically reflect on the study by considering their comments. Success then is then two-fold and translates into the completion of the study; presentation of the study at a conference and a publication of a journal article. Furthermore, learning to find peer reviewed journal articles and ordering new books and journals via the library has increased the range of my research which has led me to direct my students to use credible references and sources in their study.

As a supervisor I could say I have learned to read with my pen. My critical reflection of the students' work allows me to assist to connect thoughts in a scientific way and therefore develops my own critical thinking skills, allowing my thoughts to become more complex. As a supervisor I have learned how to sustain a logical argument in an organised concise way; and identify various debates and arguments regarding a particular issue.

My identity as an academic has shifted as an academic since I started supervising postgraduate studies. Postgraduate supervision has placed me as a social subject within my academic discourse. Through my experiences of supervision, I have partially established my academic identity for possible inclusion into the broader academic community.

\section{Conclusions and Recommendations}

The process of self-reflection has enabled me to reflect on my development as an academic. It has also allowed me to trace the reconstruction of my academic identity over the years. Whereas in the past my key role was undergraduate study only, l've now had to reconstruct and re-negotiate my identity to integrate the scholarship of research. By reflecting on my postgraduate experiences, I have analysed my ability to make professional judgements which have over the years contributed positively to my professional development, to name a few, supervision experience, postgraduate graduates, research publications, conference presentations and funding opportunities.

However, would the process of postgraduate supervision have been a lot easier if I was subjected to a training module on postgraduate supervisory practices before I started supervising postgraduate students? I therefore argue that in as much as this process has been a journey of discovery for me as a UoT academic, I would recommend that, to add 
credence to the supervisory process and to the novice supervisors experiences, a structured postgraduate supervision module is introduced as a core study module for all first-time supervisors before they embark on their journey of supervision. This process could possibly assist the novice researcher's journey of identity re-negotiation for possible inclusion into the broader academic community and to build further supervision capacity at the fairly newly established UoT's in South Africa.

\section{References}

Amundsen, C., \& McAlpine, L. (2009). Learning Supervision: Trial by Fire. Innovations in Education and Teaching International, Vol. 46 No. 3, 331-342.

Athens, L. (1994). The self as a soliloquy. Sociological Quarterly, 35, 521-532.

Bates, A.J. \& Pardo, L.S. (2006). Pre-service teachers learn to do action research. Academic Exchange Fall, 250-254.

Boyer, E.L. (1990). Scholarship reconsidered: Priorities of the professoriate. Princeton: NJ Carnegie Foundation.

Chetty, R. (2010). The scholarship of research in teacher education in a higher education institution in transition: issues of identity. Education papers and reports. paper 29. [Online] Available: http://dk.cput.ac.za/ed_papers/29 (June 05, 2013)

Creswell, J.W. (2008). Narrative research designs.(3rd ed)). Upper Saddle River: NJ Pearson Education.

Ezzy, D. (1998). Theorizing narrative identity: symbolic interactionism and hermeneutics. The Sociological Quarterly, 39, 239-263.

Etlers, L. H. (2006). Action research: The ultimate mirror test. The Delta Kappa Camma Bulletin Spring, 14-29.

Giddens, A. (1991). Modernity and self-identity: self and society in the late modern age. Polity Press: Cambridge.

Gatfield, T.J. (2005). An investigation into PhD supervisory management styles: development of a dynamic conceptual model and its managerial implications. Journal of Higher Education Policy and Management, vol. 27(3) 311-325.

Gurr, G.M. (2001). Negotiating the rackety bridge - a dynamic model of aligning supervisory style with research and student development. Higher education and Research Development, 20 (1), 81-92.

Hall, S. (1996). Who need 'identity'? In S. Hall and P. Du Gay (Eds). Questions of cultural identity. London: Sage.

Higher Education South Africa (2008). Strategic plan. [Online] Available at www.hesa.org/hesa/strategicplan.com (Retrieved March 16, 2009).

May, T. (2004). An evaluation of goal clarity, trust in management and perceptions of organisational readiness for change at Durban Institute of Technology. Masters Thesis, Unpublished. Durban: Durban Institute of Technology. Durban.

McNiff, J.,\& Whitehead, J. (2000). Action research in organisations. New York: Routledge.

Ministry of Education 2001. National Plan for Higher Education. [Online] Available at www.education.gov.za/document/policies/national planhighereducation.com (Retrieved March 14, 2009).

Pare', A., McAlpine, L., \& Starke-Meyerring, D. (2006). Entering the text: Learning doctoral rhetoric. Paper presented at the American Educational Research Association in San Fransisco.

Pinnegar, S., \& Hamilton, M.L. (2009). Self-study of practice as a genre of qualitative research. New York: Springer.

Pityana, N.B. (2004). Higher education in South Africa: Future perspectives. [Online] Available at www.unisa.ac.za/contents/about /principle/docs/AltronAwardsspeech, (retrievied March 17, 2009).

Schwandt, T. (1998). Constructivist, interpretivist approaches to human inquiry. In Denzin, N. and Lincoln, Y. (eds), The Landscape of Qualitative Research Theoretical Issues (pp. 221-259). Sage: Newbury Park, CA,.

Stryker, S. (2007). Identity theory and personality theory: mutual relevance. Journal of Personality, 75(6), 1083-1102.

White, J. (2012). Scholarly Identity. In T. Fitzgerald, J. White, \& H.M. Gunter (Eds.) Hard labour? Academic work and the changing landscape of higher education (pp.41-64). Emerald Group Publishing Limited: Newbury Park. 